\title{
Correction to: Social capital and the problem of opportunistic leadership: the example of Koreans in Japan
}

\section{J. Mark Ramseyer ${ }^{1}$ (1)}

Accepted: 18 November 2021

(c) Springer Science+Business Media, LLC, part of Springer Nature 2021

\section{Correction to: European Journal of Law and Economics (2021) 52:1-32 https://doi.org/10.1007/s10657-020-09682-2}

In response to questions that have been raised since the publication of my article

Ramseyer, J.M. Social capital and the problem of opportunistic leadership: the example of Koreans in Japan. Eur J Law Econ 52, 1-32 (2021). https://doi.org/10. 1007/s10657-020-09682-2

I want to correct and amend the article as follows:

The reference in footnote 8 to Ryang (2007) is incorrect. Professor Ryang (2007) estimates the number of Korean deaths at 6000 , not 20,000. I apologize for this error.

The source for "Shimbun 2017" is "Sankei Shimbun."

The publisher for Ko's book is the "Akashi shoten."

The population figures for Jeju island at the close of Section 5.1.1 are incorrect.

"Zaishuto 4-3 jiken" was posted on December 6, 2006. The date in the bibliography is incorrect. The Japanese pronunciation for Jeju is Saishuto rather than Zaishuto.

Footnote 2 should read: "Although Koreans were Japanese citizens before the war, the Japanese government did not draft Korean men into the military. It did not start recruiting Koreans to work in Japan until 1939. For 1939, the government approved the recruitment of 85,000 Koreans. By the end of the year, however, the Health Ministry had approved only 38,959 recruits, and of these only 19,135 had settled in Japan (Naimu sho 1939, 997). In a 1939 report, the Ministry of Interior stressed the need to take the severest care in selecting workers for the recruitment drive (Naimu sho 1939, 998). It reported, for example, that some of workers hired

The original article can be found online at https://doi.org/10.1007/s10657-020-09682-2.

\section{J. Mark Ramseyer}

ramseyer@law.harvard.edu

1 Harvard Law School, Cambridge, USA 
had used the recruiting effort to bypass immigration restrictions (Naimu sho 1939, 998, 1009; there was significant illegal immigration into Japan at the time-see id., 928-929). It also noted that some of the workers hired under the recruiting drive had impersonated someone else in order to circumvent the background checks used in that drive (Naimu sho 1939, 998, 1010).

The Japanese government did not formally conscript Koreans to work in factories and mines until the fall of 1944. That year, it began drafting Koreans for civilian work as part of a general program of mobilizing all Japanese citizens, whether on the Korean peninsula or on the Japanese mainland (e.g., Lee 2019, 67-69)."

\section{References}

Lee, W. (2019). "Kyosei doin" no shinwa [The Myth of "Mass Mobilizatioon"]. In Y. Lee (Ed.), Hannichi shuzoku shugi [Anti-Japanese Tribalism] (pp. 66-74). Bungei shunju, Tokyo.

Naimu sho. (1939). Naichi zaiju Chosen jin undo [Japan-Resident Korean Movements]. Reprinted in Zainichi Chosenjin kankei shiryo shusei [Collection of Materials Related to Japan-Resident Koreans] (Vol. 4, pp. 885) (181) et seq. Tokyo: San'ichi shobo, 1976.

Publisher's Note Springer Nature remains neutral with regard to jurisdictional claims in published maps and institutional affiliations. 